\title{
Estimation of Macro-Nutrients in Domestically Processed Cauliflower Leaf Powder
}

\author{
Sagarika Chakraborty ${ }^{1 *}$, Santa Datta (De $)^{2}$ \\ ${ }^{1}$ Research Scholar, Department of Home Science, University of Calcutta, India \\ ${ }^{2}$ Professor, Department of Home Science, University of Calcutta, India \\ *Author for Correspondence \\ E-mail: sagarikachakraborty82@gmail.com \\ Ph. No.: (91) 9051309211
}

\begin{abstract}
In India, under-nutrition is widely prevalent in spite of availability of various types of highly nutritious, less familial, lowcost, nutritious green leafy vegetables (GLVs). Cauliflower (Brassica oleraceae) leaf is a widely grown, neglected, nutritious GLV which is wasted due to ignorance of the common people. It can be explored to improve nutritional scenario of our country. Quantitative estimation of macro-nutrients in domestically processed dry cauliflower leaf powder (CLP) showed that $100 \mathrm{~g}$ CLP contains 319.88 Kcal energy, $40.14 \mathrm{~g}$ carbohydrate, $27.77 \mathrm{~g}$ protein, $5.36 \mathrm{~g}$ fat, $8.55 \mathrm{~g}$ fibre, $13.98 \mathrm{~g}$ total ash and $4.2 \mathrm{~g}$ moisture. It can be used to enrich many common recipes like roti, puri, paratha, soup, besan, dal etc. Cauliflower leaves, which are generally thrown away, can be utilized to improve the nutritional status of the population.
\end{abstract}

Keywords: Cauliflower leaves, drying, macronutrients, cauliflower leaf powder (CLP)

\section{Introduction}

In our country both poverty and malnutrition are widespread which hinders national development in spite of availability of various types of nutritious, cheap green leafy vegetables (GLVs). For instance, cauliflower leaf is a neglected, seasonal leafy vegetable which can be explored to improve the nutritional scenario of our country.

Cauliflower (Brassica oleraceae var. Botrytis, family Brassicaceae) is a popular cole vegetable, grown extensively in different parts of India. But the leaves of cauliflowers are usually thrown away in garbage as a non-edible waste material. However, these leaves can easily be dried by homebased methods and can be included in the daily diets of common people as a source of protein, energy and micronutrients [10].

Cauliflower leaves are cheap and within reach of common man but they are available only for a short period of time. They are highly perishable due to their high moisture content (80g \%). According to the Food Composition Table provided by the National institution of Nutrition, Hyderabad, India, $100 \mathrm{~g}$ fresh Cauliflower leaves contain $5.9 \mathrm{~g}$ protein, $1.3 \mathrm{~g}$ fat, $7.6 \mathrm{~g}$ carbohydrate, $2 \mathrm{~g}$ crude fiber and $66 \mathrm{Kcal}$ energy [7].

Cauliflower leaves can be dried by various methods but the nutritive value of cauliflower leaf powder depends on the drying method used.

- Nutrient analysis of shade-dried $\left(27-37^{0} \mathrm{C}\right)$ Brassica oleracea leaves showed that dry cauliflower leaf is a good source of protein $(28.98 \mathrm{~g} / 100 \mathrm{~g})$, containing only little moisture (2.52\%) (Buvaneswari, K.M.et.al: 2014) [3].

- Mogra, R.et.al (2012) dried cauliflower leaves using mechanical drier $\left(40^{\circ} \mathrm{C}\right.$ for 22 hours $) .100 \mathrm{~g}$ CLP contained $12.55 \mathrm{~g}$ moisture, $17.67 \mathrm{~g}$ protein, $1.76 \mathrm{~g}$ fat, $8.20 \mathrm{~g}$ fiber, $15.32 \mathrm{~g}$ ash and $256 \mathrm{Kcal}$ energy [4].
- Wani, T.A.et.al. (2011) dried blanched cauliflower leaves using hot air oven $\left(40^{\circ} \mathrm{C}\right.$ for $4-6$ hours) and then powdered. Leaf powder contained $2.41 \mathrm{~g} \%$ moisture and $26.54 \mathrm{~g} \%$ protein [5].

- Khan, A.D.et al.(2004) prepared leaf protein concentrates (LPC) from cauliflower leaves by pulping, pressing and protein coagulation by heating at $80+2^{\circ} \mathrm{C}$ followed by drying. LPC contained 48.11-61.68\% protein [6].

- In another study, Khanna, K.et.al. (2002) prepared LPC of cauliflower leaves using sun, shades and cabinet drying methods. $100 \mathrm{~g}$ of blanched cabinet dried LPC contained $23.9 \mathrm{~g}$ protein [9].

- Cauliflower leaf protein concentrate contained nutritionally adequate amounts of lysine and tryptophan but it is deficient in cystine and methionine (Goel, U. et. al.; 1997) [11].

\section{Materials \& Methods}

In the present study, cauliflower leaves are domestically processed and converted into dry cauliflower leaf powder and then quantitatively analyzed for macronutrients [2].

\section{Sample Preparation:}

Fresh cauliflower leaves were collected, dried and powdered. The detail procedure is as follows: 


\section{International Journal of Science and Research (IJSR) \\ ISSN (Online): 2319-7064}

Index Copernicus Value (2013): 6.14 | Impact Factor (2014): 5.611

Fresh cauliflower leaves were collected from the local market

Good quality leaves were thoroughly cleaned with water

Excess water was removed by soaking the leaves in between the folds of dry cloth

The leaves were roasted for 10 minutes

Roastedleaves were finely grinded into powder

The freshly prepared CLP was cooled at room temperature and kept in air tight container for future use.

\section{Macronutrient estimation of Cauliflower Leaf Powder}

A.Estimation of moisture [8],[1]:Moisture content was determined by drying $10 \mathrm{~g}$ sample in an oven at $105^{\circ} \mathrm{C}$ and cooling in desiccator in a repetitive manner until a constant weight was achieved.

$$
\text { Moisture }(\%)=\frac{\left(w_{i}-w_{f}\right) * 100}{w_{i}}
$$

where $\mathrm{w}_{\mathrm{i}}$ is the initial weight and $\mathrm{w}_{\mathrm{f}}$ is the final weight.

B. Estimation of fat [8]: Crude ether extract of the moisturefree sample was used to estimate fat content. $5 \mathrm{~g}$ dry sample was weighed accurately into a thimble which was placed in a Soxhlet apparatus and extracted with anhydrous ether for 16 hours. The ether extract was filtered into a weighed conical flask. Now the ether was evaporated, cooled in a desiccator and weighed.

C.

$$
\text { Fat content }(\mathrm{g} / 100 \mathrm{~g} \text { sample })=\frac{w_{e} * 100}{w_{s}}
$$

Where $\mathrm{w}_{\mathrm{e}}$ is the weight of ether extract and $\mathrm{w}_{\mathrm{s}}$ is the weight of the sample.

\section{D.Estimation of fiber [8]:}

$2 \mathrm{~g}$ moisture and fat free sample $\left(\mathrm{w}_{\mathrm{s}}\right)$ was taken in a $500 \mathrm{ml}$ beaker, $200 \mathrm{ml}$ boiling $0.255 \mathrm{~N}(1.25 \% \mathrm{~W} / \mathrm{V})$ sulphuric acid was added, boiled for 30 minutes keeping the volume constant by frequently adding water and the mixture was then filtered through a muslin cloth and the residue washed with hot water till free from acid. The material was then transferred to the same beaker, $200 \mathrm{ml}$ boiling $0.313 \mathrm{~N}$ $(1.25 \%) \mathrm{NaOH}$ added, boiled again for 30 minutes, the mixture was again filtered through muslin cloth and the residue was washed with hot water till free from alkali, followed by washing with some alcohol and ether. It was then transferred to a crucible, dried overnight at $80-100^{\circ} \mathrm{C}$ and weighed $\left(\mathrm{w}_{\mathrm{e}}\right)$. The crucible was heated in a muffle furnace at $600^{\circ} \mathrm{C}$ for $2-3$ hours, cooled and weighed again $\left(\mathrm{w}_{\mathrm{a}}\right)$. The difference in the weights $\left(\mathrm{w}_{\mathrm{e}}-\mathrm{w}_{\mathrm{a}}\right)$ represents the weight of the crude fiber.

$$
\begin{aligned}
& \text { Crude fibre ( } g / 100 \text { g sample }) \\
& \qquad=\frac{\left[100-\left(\text { moisture }^{*}+f a t^{*}\right)\right]\left(w_{e}-w_{a}\right)}{w_{s}}
\end{aligned}
$$

Where, $\mathrm{w}_{\mathrm{s}}$ is the weight of the sample.

*g/100g sample.

\section{E. Estimation of total protein by macro Kjeldahl method [8]:}

$2 \mathrm{~g}$ sample was taken into a dry Kjeldahl flask and digested with $5 \mathrm{~g}$ digestion mixture (98 parts $\mathrm{K}_{2} \mathrm{SO}_{4}+2$ parts $\mathrm{CuSO}_{4}$ ) and $20 \mathrm{ml}$ conc. $\mathrm{H}_{2} \mathrm{SO}_{4}$ for $4-5$ hours at $100^{\circ} \mathrm{C}$. The content was then cooled, diluted with distilled water and the mixture made alkaline by adding excess of $40 \% \mathrm{NaOH}$. The ammonia liberated was distilled into a receiver containing $25 \mathrm{ml}$ of $\mathrm{N} / 10 \mathrm{H}_{2} \mathrm{SO}_{4}$. The excess of acid in the receiver was back titrated against $\mathrm{N} / 10 \mathrm{NaOH}$ using 3 drops of methyl red indicator. A reagent blank was similarly digested and distilled. This titre value was subtracted from the value obtained for the sample to get the true titre value , , $\mathrm{b}^{\text {ee }}$.

Calculation: If , $\mathrm{a}^{\mathrm{ee}} \mathrm{g}$ of the sample was taken and if ,, $\mathrm{b}^{\mathrm{ee}}$ and ,ce $\mathrm{ml}$ of alkali of normality, ,de were required for back titration and to neutralize $25 \mathrm{ml}$ of $\mathrm{N} / 10 \mathrm{H}_{2} \mathrm{SO}_{4}$ respectively then

$$
\text { Protein content }(\mathrm{g} / 100 \mathrm{~g} \text { of sample })=\frac{(c-b) *(14 * d) * 6.25 * 100}{a * 1000}
$$

\section{F. Estimation of ash [8]:}

$5 \mathrm{~g}$ sample was weighed accurately into a porcelain crucible and was gently heated over a flame until the mass was completely charred. It was then transferred to muffle furnace, heated at $600^{\circ} \mathrm{C}$ for 4 hours, cooled in a desiccator and weighed again. To ensure completion of ash preparation the crucible was again heated in the muffle furnace for 4 hours. This was repeated till two consecutive weights were the same.

$$
\text { Ash content }(\mathrm{g} / 100 \mathrm{~g} \text { of sample })=\frac{w_{a} * 100}{w_{s}}
$$

where $\mathrm{w}_{\mathrm{a}}$ is the weight of ash and $\mathrm{w}_{\mathrm{s}}$ is the weight of the sample.

\section{G. Carbohydrate estimation [8]:}

The content of the available carbohydrate was determined by difference, i.e., by subtracting from 100 the sum of the values (per $100 \mathrm{~g}$ ) for moisture, protein, fat, ash and crude fiber.

\section{H. Energy estimation [8]:}

The energy value of the $100 \mathrm{~g}$ of food sample was calculated by using the following formula -

$$
\text { Energy con tent }=4 * w_{c}+4 * w_{p}+9 * w_{f}
$$

where $\mathrm{w}_{\mathrm{c}}$ is the carbohydrate content $(\mathrm{g} / 100 \mathrm{~g}), \mathrm{w}_{\mathrm{p}}$ is the protein content $(\mathrm{g} / 100 \mathrm{~g})$ and $\mathrm{w}_{\mathrm{f}}$ is the fat content $(\mathrm{g} / 100 \mathrm{~g})$.

\section{Volume 5 Issue 2, February 2016}




\section{International Journal of Science and Research (IJSR) \\ ISSN (Online): 2319-7064}

Index Copernicus Value (2013): 6.14 | Impact Factor (2014): 5.611

\section{Result and Discussion}

Quantitative analysis of macronutrient content of cauliflower leaf powder revealed the following values.

Macronutrient contents of cauliflower leaf powder (CLP)

\begin{tabular}{|c|c|c|c|}
\hline Sl. No. & Parameters assessed & Results & Units \\
\hline 1 & Energy & 319.88 & $\mathrm{Kcal} / 100 \mathrm{~g}$ \\
\hline 2 & Protein & 27.77 & $\mathrm{~g} / 100 \mathrm{~g}$ \\
\hline 3 & Carbohydrate & 40.14 & $\mathrm{~g} / 100 \mathrm{~g}$ \\
\hline 4 & Fat & 5.36 & $\mathrm{~g} / 100 \mathrm{~g}$ \\
\hline 5 & Crude fiber & 8.55 & $\mathrm{~g} / 100 \mathrm{~g}$ \\
\hline 6 & Ash & 13.98 & $\mathrm{~g} / 100 \mathrm{~g}$ \\
\hline 7 & Moisture & 4.2 & $\mathrm{~g} / 100 \mathrm{~g}$ \\
\hline
\end{tabular}

Cauliflower leaf, a cheap, seasonal, nutritious green leafy vegetable, is economically within the reach of common man. These leaves are wasted by the common people due to their ignorance. Fresh cauliflower leaves, containing 80\% moisture, are highly perishable but it can easily be converted into a dry, powdered, supplementary product which is rich in protein, calcium and iron.

Cauliflower leaf protein concentrate contains lysine and tryptophan in nutritionally adequate amounts but it is deficient in cystine and methionine. Since there is a similarity between the amino acid composition of pulses and cauliflower leaf powder (CLP), so it can be used to supplement cereal protein and as a substitute of pulse protein. It is useful to improve nutritionally poor diets. Many tasteful recipes can be prepared using CLP.

Laboratory estimation of cauliflower leaves powder showed that CLP is an energy rich $(319.88 \mathrm{Kcal} / 100 \mathrm{~g})$, high protein $(27.77 \mathrm{~g} / 100 \mathrm{~g})$, low fat $(5.36 \mathrm{~g} / 100 \mathrm{~g})$, low carbohydrate $(40.14 \mathrm{~g} / 100 \mathrm{~g})$ and fiber rich $(8.55 \mathrm{~g} / 100 \mathrm{~g})$ food. Higher value of ash content $(13.98 \mathrm{~g} / 100 \mathrm{~g})$ indicates high mineral content of the product. This dry food contains only little moisture $(4.2 \mathrm{~g} / 100 \mathrm{~g})$ which increases the shelf life of the powder. In pre-cooked (roasted) CLP, the enzymes present in fresh cauliflower leaves were deactivated which further increases the shelf life of the food and makes the food ready-to-use.

\section{Conclusion}

Cauliflower (Brassica oleraceae) leaf is a widely grown, neglected, nutritious GLV which can be dried with a little time and effort to prepare a low cost, nutritious supplementary food. Quantitative estimation of macronutrients in domestically processed dry cauliflower leaf powder (CLP) indicates that it is rich in energy, protein and minerals which can be used to enrich common recipes like roti, puri, paratha, soup, besan, dal etc. Cauliflower leaves, which are generally thrown away, can be utilized to improve the nutritional status of the population.

\section{References}

[1] Maboodurrahman and S.S. Birari, "Sensory and Analytical Study of Oats Chocolate Chips Cookies", International Journal of Science and Research,4 (10),pp. 793-796, 2015.

[2] S. Chakraborty, A. Mandal, K. Mondaland, S.D. De, "Preparation of calcium- dense cauliflower leaf powder by different methods \& selection of the most suitable method", International Journal of Current Research. 7 (9), pp. 2046220468, 2015.

[3] K.M. Buvaneswari, and G. Ramya, "A study on overall acceptability of Brassica oleracea leaves (cauliflower leaves) incorporated food products and its impact on treating anemic college going girls". International Journal of Current Research and Development, 2 (1), pp 38- 47, 2014.

[4] R Mogra, J Banga andP. Rathi, "Nutrient composition of cauliflower (Brassica oleracea var. Botrytis) leaf powder and its acceptability in fast food snacks". Food Science Research Journal, 3 (2), pp. 167-171, 2012.

[5] T.A. Wani, M. Sood andR.K. Kaul, "Nutritional and sensory properties of roasted wheat noodles supplemented with cauliflower leaf powder", Annals. Food Science and Technology, 12 (2), pp. 102-107, 2011.

[6] A.D. Khan, K. Shahzad, N. Ejaz, R. Ahmad and S. Saeed, "Optimization of conditions for extraction of protein from the waste residue leaves of some vegetables". Pakistan Journal of Biochemistry and Molecular Biology, 37 (1), pp. 30-34, 2004.

[7] C. Gopalon, B.V.Ramasastri and S.C. Balasubramanian, Nutritive Value of Indian foods, National Institute of Nutrition, Indian Council of Medical Research Hyderabad, India,2004.

[8] N. Raghuramulu, K. Nair, andS. Kalyanasundarum, A Manual of Laboratory Techniques(2nd ed.),Nutritive Value of Indian foods, National Institute of Nutrition, Indian Council of Medical Research, Hyderabad, India, 2003.

[9] Khanna K, Aggarwal M. Study on supplementation of leaf powder concentrate on vitamin-A and iron status of children (1-3 years age) [Doctoral dissertation]. Institute of Home Economics: University of Delhi, 2002.

[10] S. Kowsalya and S. Mohandas, "Acceptability and nutrient profile of cauliflower leaves (Brassica Oleracea, Var. Botrytis)", The Indian journal of nutrition and dietetics, 36 (7), pp. 332-338, 1999.

[11] U. Goel,B.L. Kawatra andS. Bajaj, "Nutritional evaluation of a cauliflower leaf protein concentrate by rat feeding", Journal of the Science of Food and Agriculture, 28 (9), pp. 786-790, 1977.

\section{Authors' Profile}

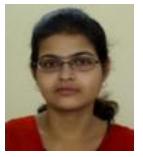

Sagarika Chakraborty received her B.Sc. and M.Sc. degrees in Food and Nutrition (Home Science) from University of Calcutta (C.U.) in 2003 and 2005 respectively. Currently, she is a registered Ph.D. scholar in Food \& Nutrition in the Department of Home Science, University of Calcutta, Kolkata, India. She has published papers in various international journal and national conferences. She is interested in the development of low cost nutritious supplementary foods and their effects on experimental animals.

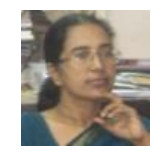

Prof. Santa Datta (De) obtained her B.Sc. and M.Sc. degrees in Food and Nutrition from University of Calcutta (C.U.) in 1977 and 1982 respectively. She was ranked $1^{\text {st }}$ in merit list (gold medalist) in both the examinations. She was awarded Ph.D. in 1991 from University of Calcutta, and in the same year she joined as a lecturer in C.U. She has been working in the field of developing new supplementary foods for a long time. 